\title{
The Effects of Different Titanium Surfaces on the Behaviour of Osteoblast-Like Cells
}

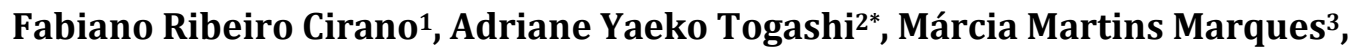 \\ Francisco Emílio Pustiglioni' ${ }^{4}$ Luiz Antônio Pugliesi Alves Lima ${ }^{4}$ \\ ${ }^{1}$ Department of Periodontology, Paulista University (UNIP), São Paulo, Brazil \\ ${ }^{2}$ Department of Dental Implantology, State University of Western Parana (UNIOESTE), Cascavel, Brazil \\ ${ }^{3}$ Department of Dentistry, University of São Paulo, São Paulo, Brazil \\ ${ }^{4}$ Department of Periodontology, University of São Paulo, São Paulo, Brazil \\ Email: ${ }^{*}$ adriane.togashi@unioeste.br, ${ }^{*}$ adtogashi@gmail.com
}

Received 25 May 2015; accepted 26 June 2015; published 29 June 2015

Copyright (C) 2015 by authors and Scientific Research Publishing Inc.

This work is licensed under the Creative Commons Attribution International License (CC BY).

http://creativecommons.org/licenses/by/4.0/

(c) (i) Open Access

\section{Abstract}

This study investigated the influence of different titanium surfaces on the differentiation of rat osteoblast-like cells (osteo-1). Osteo-1 cells were cultured on the following titanium surfaces: 1) pretreated, smooth surface (PT); 2) sandblasted and acid etched surface (SLA); and 3) sandblasted and acid-etched surface rinsed under nitrogen protection to prevent exposure to air and preserved in isotonic saline solution (modSLA). Cell metabolism, total protein content, collagen content and alkaline phosphatase (AP) activity and the formation of calcified nodules were analyzed. The titanium surface did not influence cell metabolism, total protein content and collagen content. The SLA surface influenced cell differentiation, with the observation of a significant reduction of AP activity and formation of calcified nodules after 21 days compared to the PT surface. No difference was observed between the PT and modSLA surfaces. All titanium surfaces tested permitted the full expression of the osteoblast phenotype by osteo-1 cells, including matrix mineralization.

\section{Keywords}

Titanium, Dental Implants, Osteoblasts

\section{Introduction}

Various in vitro studies have shown that the surface roughness of titanium reduces the proliferation of osteoblast-like cells and increases cell differentiation by increasing alkaline phosphatase (AP) activity, protein synthesis, osteocalcin production and the formation of bone-like nodules [1]-[3]. In vitro studies also have shown that

\footnotetext{
*Corresponding author.
}

How to cite this paper: Cirano, F.R., Togashi, A.Y., Marques, M.M., Pustiglioni, F.E. and Lima, L.A.P.A. (2015) The Effects of Different Titanium Surfaces on the Behaviour of Osteoblast-Like Cells. J. Biomedical Science and Engineering, 8, $380-388$. 
rough and chemically activated surfaces provide the ideal conditions for direct protein adsorption [4] and alter the adsorption of fibronectin and albumin [5] due to modifications in their ionic state [6]. Ramires et al. [7] demonstrated that titanium oxide acts as a nucleation substrate for calcium phosphate crystals. The biological activity of $\mathrm{TiO}_{2}$ also influences protein adsorption to the titanium surface [6].

The quality of titanium surfaces can be described in terms of surface chemistry, which refers to the critical surface tension (CST) of a material [8]. The CST provides an indicator of the potential of cell adhesion (bioadhesiveness) or surface wettability [9]. Increased wettability thus improves the interaction between the implant surface and the biological environment [10]. In addition to changes in surface topography, some authors have proposed that the chemical modification of titanium surfaces, especially protection of sandblasted and acid etched (SLA) surfaces from air contamination, may improve osteoblast function [11]. This protection is achieved by immersing the surface in isotonic saline solution (modSLA) [4] [12].

Although many studies have reported improved results when cells were grown on rough titanium surfaces, there are reports showing that an increase in the roughness of titanium surfaces does not affect or even reduce cell function or bone formation [13]-[16].

The objective of the present study was to investigate the influence of SLA and modSLA surfaces on the metabolism and differentiation of rat osteoblast-like cells (osteo-1).

\section{Experimental Methods}

\subsection{Sample Preparation}

Sixty titanium discs with surfaces identical to those used in commercially available dental implants were fabricated. Titanium discs, measuring $15 \mathrm{~mm}$ in diameter and $1 \mathrm{~mm}$ in thickness, were manufactured from grade 2 unalloyed titanium (ASTM F67) by Institut. Straumann AG (Waldenburg, Switzerland). These discs had one of following surface topographies: 1) pretreated (PT) disc with a low mean roughness (Ra) which was degreased by washing in acetone, processing through $2 \%$ ammonium fluoride/ $2 \%$ hydrofluoric acid $/ 10 \%$ nitric acid solution [17]; 2) sandblasted and acid-etched (SLA) disc which was further coarse grit-blasted with $0.25-0.50 \mathrm{~mm}$ corundum grit followed by acid etching, as described previously [17]; 3) sandblasted and acid-etched disc rinsed under nitrogen protection to prevent exposure to air and preserved in isotonic saline solution (modSLA) [4] [18]. Before use in the cell culture experiments, PT and SLA discs were washed and sterilized in an autoclave [17] [19]. The modSLA discs were sterilized by gamma irradiation and were provided in sealed wrappings and immersed in isotonic saline by the Straumann AG.

\subsection{Cell Culture}

A cell line derived from parietal bone tissue of newborn albino Wistar rats (osteo- 1 cells) was obtained by enzymatic isolation. The culture medium was supplemented with sodium $\beta$-glycerophosphate, ascorbic acid and dexamethasone after semi-confluence as initially described by Deboni, Jaeger and Araújo [20] and Lavos-Valereto et al. [21] and recently characterized by Togashi et al. [22]. The cells were cultured in Dulbecco's modified Eagle medium (DMEM, Sigma Chemical Co., St. Louis, MO, USA) containing 10\% fetal bovine serum (Cultilab, Campinas, SP, Brazil) and 1\% antibiotic-antimycotic solution (Sigma). The cells were maintained in a humid atmosphere containing $5 \%$ carbon dioxide at $37^{\circ} \mathrm{C}$. Cell growth was monitored at intervals of $24 \mathrm{~h}$. The cells were plated onto the titanium discs at a concentration of $3 \times 10^{3}$ cells per well and the discs were placed in 24-well culture plates according to the growth curve of osteo-1 cells determined by the MTT method [23]. The media were changed every other day (Figure 1).

\subsection{Cell Metabolism}

For cell metabolism analysis, the cells were cultured for $24 \mathrm{~h}$, enzymatically removed from the discs and counted in a hemocytometer [14]-[16].

\subsection{Analysis of Total Protein Content}

Total protein content was calculated after 7, 14 and 21 days of culture by the modified method of Lowry [24]. Total protein content was used to indirectly quantify the number of cells on the discs over time. 


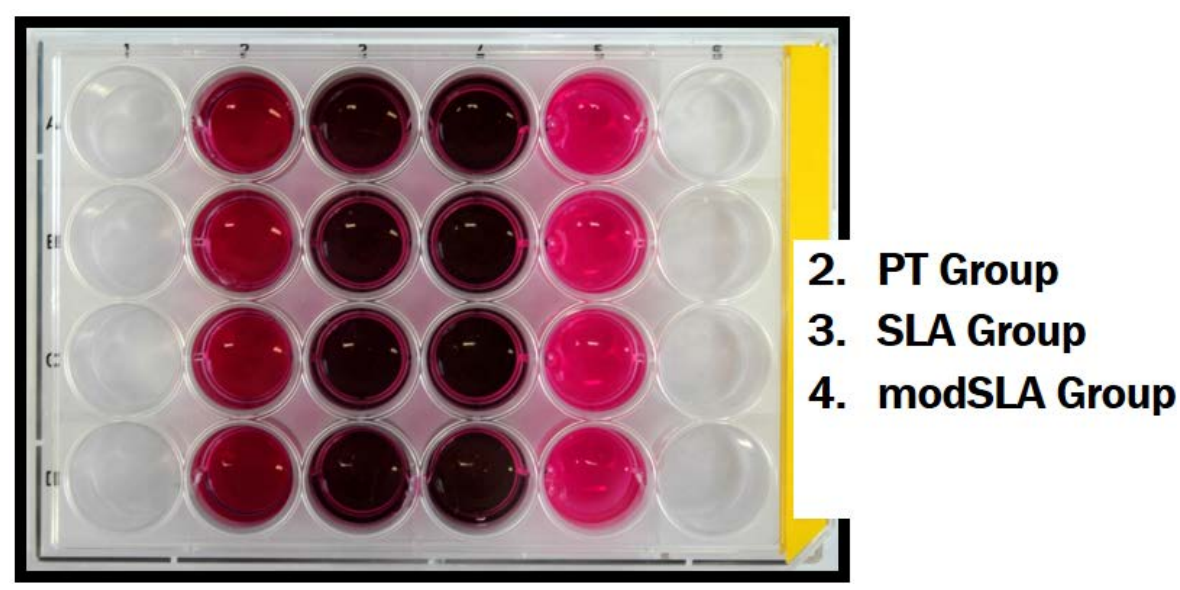

Figure 1. Osteo-1 cells plated onto the PT, SLA and modSLA discs at a concentration of 3 $\times 10^{3}$ cells per well and the discs placed in 24-well culture plates.

\subsection{Analysis of Collagen Content}

Collagen content was calculated after 7, 14 and 21 days of culture according to the method of Reddy and Enwemeka [25] and normalized to total protein content.

\subsection{Analysis of Alkaline Phosphatase Activity}

AP activity was assayed after 7, 14 and 21 days of culture as the release of thymolphthalein from thymolphthalein monophosphate [14]-[16] using a commercial kit (Labtest Diagnostica AS, Lagoa Santa, MG, Brazil) and normalized to total protein content.

\subsection{Evaluation of the Formation of Calcified Nodules}

After 21 days of culture, the discs were processed for staining with Alizarin red (Sigma), which stains nodules rich in calcium. The specimens were analyzed with an image analyzer (Image Tool, University of Texas Health Science Center, San Antonio, TX, USA) as described previously [14]-[16].

\subsection{Statistical Analysis}

The data were submitted to analysis of variance (ANOVA), complemented by the Tukey test. The KruskalWallis test was used when the variances were unequal. A level of significance of $5 \%(p<0.05)$ was adopted.

\section{Results}

\subsection{Cell Metabolism}

Cell metabolism was not affected by the titanium surface topography $(\mathrm{p}=0.6407)$ (Figure 2).

\subsection{Total Protein Content}

The topography of the titanium surface did not influence total protein content at any of the time points studied.

The highest total protein content was observed for the SLA group at 21 days. No significant differences between groups were observed after 7, 14 or 21 days of culture.

The results showed a time-dependent increase in total protein for the SLA group between 7 and 21 days. There was a time-dependent increase in total protein in the PT group and modSLA group between 7 and 14 days (Figure 3).

\subsection{Collagen Content}

The topography of the titanium surface did not influence collagen content at any of the time points studied $(\mathrm{p}=$ 0.5502) (Figure 4). 


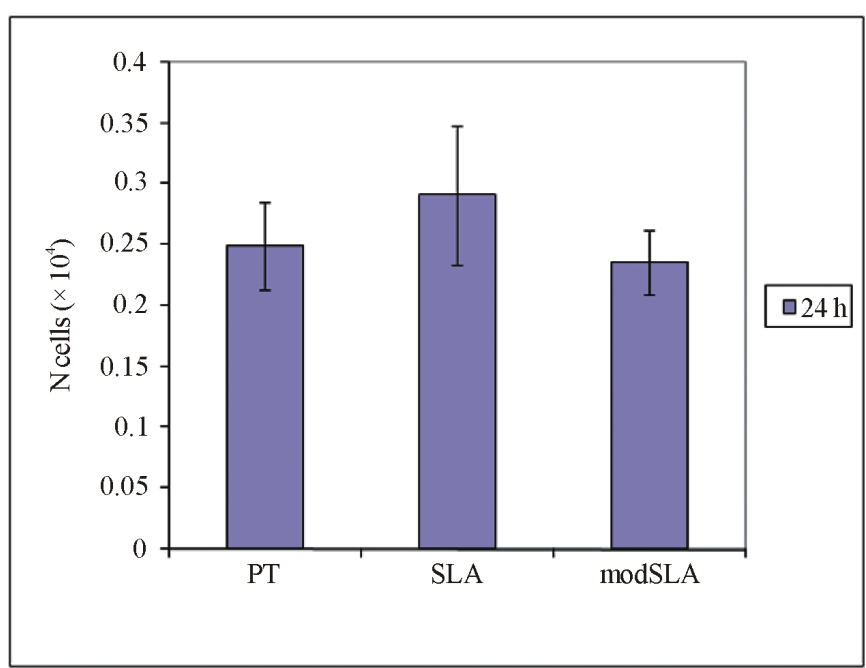

Figure 2. Effect of different titanium surfaces on the number of osteo-1 cells cultured for $24 \mathrm{~h}$. Data are the mean \pm standard error of the mean of one experiment performed in quadruplicate (ANOVA, $\mathrm{p}=0.6407$ ).

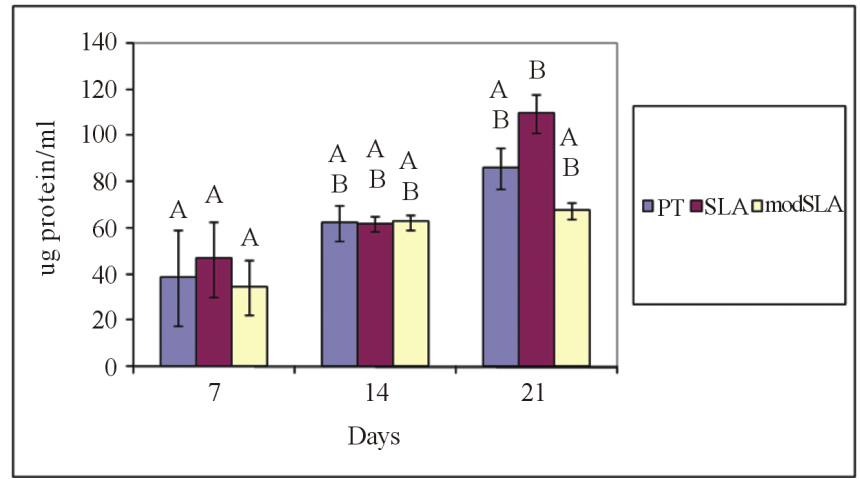

Figure 3. Total protein content of osteo-1 cells evaluated after 7, 14 and 21 days of culture. Data are the mean \pm standard error of the mean of one experiment performed in quadruplicate (ANOVA complemented by the Tukey test, $\mathrm{p}=0.0025)$ and are expressed as $\mu \mathrm{g}$ protein $/ \mathrm{ml}$. Different letters indicate significant differences $(\mathrm{p}<0.05)$.

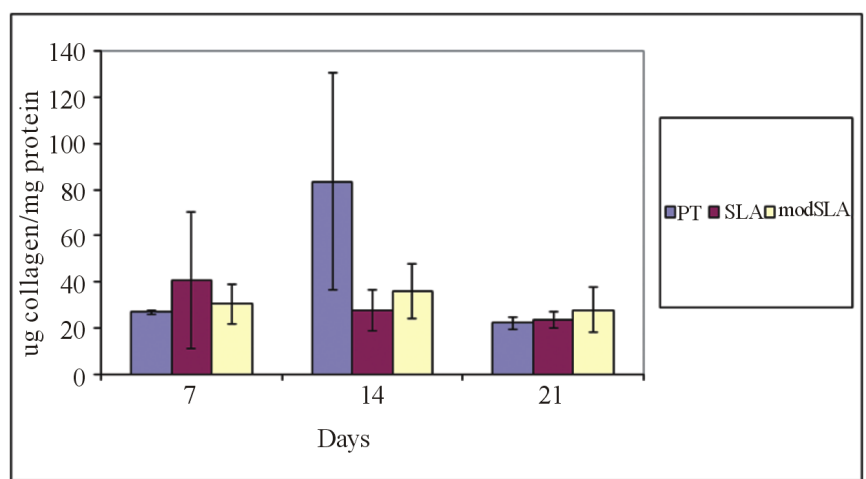

Figure 4. Collagen content of osteo-1 cells evaluated after 7, 14 and 21 days of culture. The results were normalized to total protein content (expressed as $\mu \mathrm{g}$ collagen/mg protein) and are reported as the mean \pm standard error of the mean of one experiment performed in triplicate (ANOVA, $\mathrm{p}=$ 0.5502). 


\subsection{Alkaline Phosphatase Activity}

The topography of the titanium surface influenced AP activity after 14 and 21 days of culture. The activity of this enzyme was lower in the modSLA group compared to the PT and SLA groups after 14 days and in the SLA group compared to the PT group after 21 days.

The highest AP activity was observed in the PT group after 21 days of culture. There was a time-dependent increase in AP activity in the PT and modSLA groups at all time points studied. A time-dependent increase in AP activity was observed in the SLA group between 7 and 14 days and between 7 and 21 days (Figure 5).

\subsection{Formation of Calcified Nodules}

The topography of the titanium surface influenced the formation of calcified nodules at 21 days. A significant difference was only observed between the PT and the SLA groups (PT > SLA) (Figure 6).

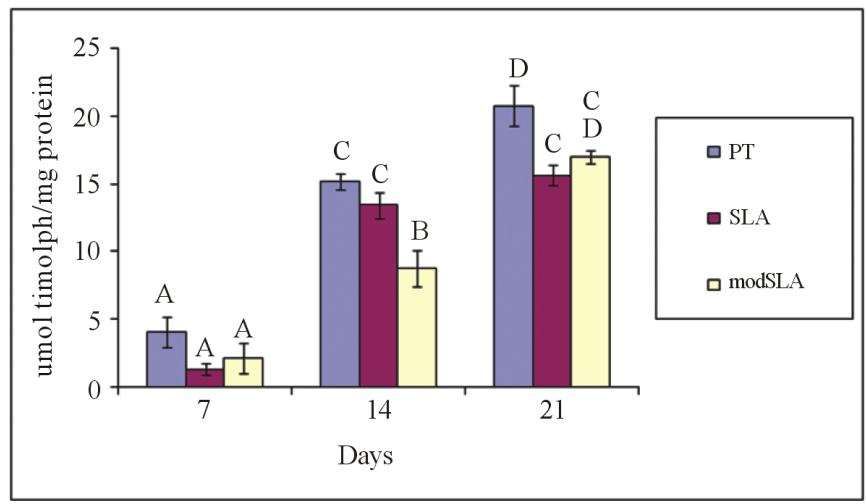

Figure 5. Alkaline phosphatase activity of osteo1 cells evaluated after 7, 14 and 21 days of culture. The results were normalized to total protein content (expressed as $\mu \mathrm{mol}$ thymolphthalein/mg protein) and are reported as the mean \pm standard error of the mean of one experiment performed in quadruplicate (ANOVA complemented by the Tukey test, $\mathrm{p}<0.0001)$. Different letters indicate significant differences $(\mathrm{p}<0.05)$.

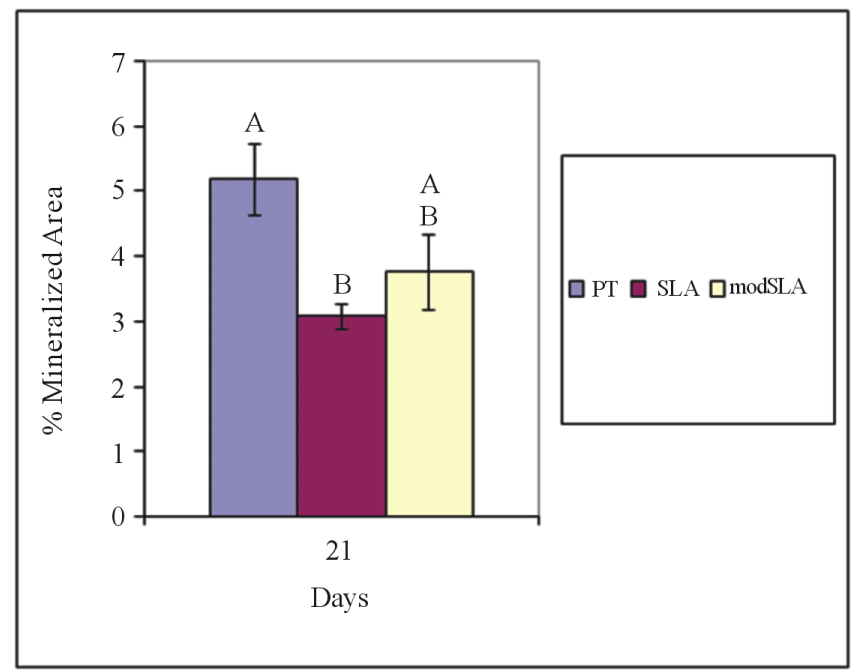

Figure 6. Formation of calcified nodules by osteo-1 cells evaluated after 21 days of culture. Data are the mean \pm standard error of the mean of one experiment performed in quadruplicate (Kruskal-Wallis test, $\mathrm{p}=0.0435$ ) and are expressed as percent mineralized area. Different letters indicate significant differences $(\mathrm{p}<0.05)$. 


\section{Discussion}

The topography of the titanium surface did not influence cell metabolism, total protein content or collagen content at any of the time points studied, but resulted in a significant reduction in AP activity in the modSLA group after 14 days of culture and in the SLA group after 21 days of culture. Furthermore, a significant reduction in the formation of calcified nodules was observed in the SLA group after 21 days of culture.

The results of this study showed that the titanium surface topography did not significantly affect cell metabolism. This finding can be explained by the fact that, although surface roughness seems to increase the area for cell adhesion, only the projected area is perceived by the cells; thus, no difference is observed between rough and smooth surfaces [26]. The cells seem to react to the morphology of the topography rather than to its roughness amplitude. Cells more easily attach to surfaces with an anisotropic roughness (machine-tooled and polished surfaces) than to isotropic surfaces (acid-etched and eletro-eroded surfaces) [26]. Zhao et al. [4] [18] demonstrated a smaller number of adhered cells on modSLA surfaces compared to SLA surfaces and on SLA surfaces compared to machine-made surfaces; however, this was not observed in the present study. According to these authors, SLA surfaces have a high surface energy, a fact that may favor the selection of cells in a more advanced stage of differentiation. In contrast, Lai et al. [23] showed that the higher surface energy of titanium surfaces (modSLA) enhanced cell metabolism in the early stage of the cell response and may act by influencing the expression of adhesion-associated molecules. However, no significant differences in the gene expression of CK14, integrin 6, integrin 4, vinculin, TGF-1 or TGF-3 has been observed between epithelial cells (HSC-2) cultured on smooth, modSLA and SLA surfaces [27].

Titanium surface topography did not affect total protein content. This finding agrees with Rosa and Beloti [14] [15] who showed that surface roughness does not influence total protein since this parameter is unable to change the secretory potential of cells. The titanium surface topography also did not affect collagen content, in contrast to the literature showing an increase in collagen content with increasing surface roughness [1] [28]. According to Lincks et al. [1], higher collagen synthesis on rougher surfaces is positively correlated with the increased production of $\mathrm{PGE}_{2}$ and latent TGF- $\beta$, which are markers of cell differentiation.

Studies investigating the associated biological mechanisms suggest that the TGF-b/BMP and WNT signaling pathways are triggered early in the interaction between osteoprogenitors and implant surfaces [29] [30] [31]. Chakravorty et al. [32] demonstrated that modified titanium implant surfaces induce differential regulation of miRNAs, which are potential regulators of the TGF-b/BMP and WNT/Ca ${ }^{2+}$ pathways during osteogenic differentiation on modified titanium implant surfaces.

Osteoblast-like cells cultured on titanium discs with SLA surfaces behave like cells cultured on other rough surfaces, with the observation of an increase in AP activity, an early marker of osteogenic differentiation [17] [19] [33] [34]. The present study showed a significant reduction in AP activity for cells grown on the modSLA surface compared to the PT and the SLA surfaces at 14 days and on the SLA surface compared to the PT surface at 21 days. Similarly, Zhao et al. [18] demonstrated lower AP activity of cells grown on modSLA surfaces compared to smooth surfaces, a finding suggesting the presence of mature secretory osteoblasts. According to these authors, the high surface energy of modSLA surfaces had no effect on AP activity, but increased the production of osteocalcin.

The topography of the titanium surface influenced the formation of calcified nodules at 21 days, with the observation of a significant reduction in the formation of calcified nodules in the SLA group. This finding agrees with Xavier et al. [16] who showed that formation of calcified nodules was significantly reduced on blasted and acid etched surfaces. One explanation for this reduction could be the release of constituent ions of the titanium, which negatively interfere with the mineralization process. The same does not apply to the modSLA surface since the sandblasted and acid-etched surface conditioned with nitrogen and preserved in isotonic saline solution may improve osteoblast function.

Although AP activity and the formation of calcified nodules after 21 days of culture were higher in the PT group compared to the SLA group, no difference was observed between the PT and modSLA groups. However, AP activity and the formation of calcified nodules after 21 days of culture tended to be lower in the SLA and modSLA groups when compared to the PT group. This finding is probably due to the selection of more differentiated cells by these surfaces, with a consequent earlier onset of differentiation characterized by elevated AP activity and subsequent expression of other markers of more advanced stages of differentiation (osteocalcin, osteopontin and bone sialoprotein) during this period and a consequent reduction in AP. Ong et al. [35] and Ku et al. [36] showed an early expression of osteocalcin on rough surfaces, an observation confirming the faster diffe- 
rentiation of cells adhered to this type of surface.

The topography (micron and submicron scale roughness) and hydrophilicity (SLA and modSLA surfaces) of implant surfaces promote a microenvironment around the implant that may enhance osseointegration. Chemical modification decreases further cell attachment and proliferation, but upregulates early osteoblastic differentiation genes [2] [3]. Genes of osteoblastic differentiation are differentially expressed by osteoprogenitor cells cultured on modSLA and SLA surfaces. Chakravorty et al. [32] showed that BMP2, BMP6, ACVR1 and FZD6 were significantly up-regulated on the modSLA surface compared to the smooth surface. BMP6 was also significantly increased on the SLA compared with the smooth surface, whereas significantly higher expression of ACVR1 was observed on the modSLA surface compared to the SLA surface. In that study, the expression of BMP2, BMP6, ACVR1 and FZD6 was measured after $24 \mathrm{~h}$ of culture on modSLA, SLA and smooth surfaces.

Boyan et al. [17] also suggested that increased AP activity results in an increase of phosphate and calcium ion levels, which may represent an increase in the area of mineralized nodules but is not accompanied by non-physiological mineral deposition on the extracellular matrix. Thus, the finding of higher AP activity and calcified nodule formation in the PT group at 21 days does not necessarily indicate a better response. The SLA and modSLA surfaces may have selected more differentiated cells, triggered an earlier onset of differentiation and induced the formation of a better organized extracellular matrix with physiological mineral deposition.

This study was not designed with sufficient power to demonstrate other markers of bone formation such as osteocalcin, bone sialoprotein, osteopontin and the earlier expression of differentiation and formation of nodules around 10 - 12 days.

Further studies evaluating other markers of bone formation and osteogenic gene expression on SLA and modSLA surfaces may help to clarify cell metabolism. In this respect, Chakravorty et al. [32] compared the early pattern of expression of a panel of miRNAs associated with human cell development and differentiation in osteoprogenitor cells cultured on three titanium implant surfaces (modSLA, SLA and smooth polished) and evaluated their prospective regulation of the initial molecular interactions on modified titanium implant surfaces. Osteogenic genes such as COL5A1, RUNX1, FOXN1, IGF1 were potential targets for miR-215. Similarly, TargetScan also predicted SCARB1, MAP2K7, VDR, NCOR2, BMPR1B, SEL1L, SMAD2, SMAD4, PPP2CA, COL4A3 genes to be possible targets for miR-125b. The miRNAs, miR-503 and miR-214 were significantly down-regulated on modSLA surface, and not on SLA surface. The miR-215 and miR-125b were the most highly down-regulated miRNAs on both the SLA and modSLA surfaces.

\section{Conclusion}

Within the limitations of this study, we conclude that the SLA and modSLA surfaces did not influence cell metabolism. The SLA surface influenced cell differentiation, with a significant reduction in AP activity and the formation of calcified nodules after 21 days of culture compared to the PT surface. However, no difference was observed between the PT and modSLA surfaces. All titanium surfaces tested permitted the full expression of the osteoblast phenotype by osteo-1 cells, including matrix mineralization.

\section{References}

[1] Lincks, J., Boyan, B.D., Blanchard, C.R., Lohmann, C.H., Liu, Y., Cochran, D.L., Dean, D.D. and Schwartz, Z. (1998) Response of MG63 Osteoblast-Like Cells to Titanium and Titanium Alloy Is Dependen ton Surface Roughness and Composition. Biomaterials, 19, 2219-2232. http://dx.doi.org/10.1016/S0142-9612(98)00144-6

[2] Klein, M.O., Bijelic, A., Toyoshima, T., Götz, H., von Koppenfels, R.L., Al-Nawas, B. and Duschner, H. (2010) Long-Term Response of Osteogenic Cells on Micron and Submicron-Scale-Structured Hydrophilic Titanium Surfaces: Sequence of Cell Proliferation and Cell Differentiation. Clinical Oral Implants Research, 21, 642-649. http://dx.doi.org/10.1111/j.1600-0501.2009.01883.x

[3] Mamalis, A.A. and Silvestros, S.S. (2011) Analysis of Osteoblastic Gene Expression in the Early Human Mesenchymal Cell Response to a Chemically Modified Implant Surface: An in Vitro Study. Clinical Oral Implants Research, 22, 530-537. http://dx.doi.org/10.1111/j.1600-0501.2010.02049.x

[4] Zhao, G., Schwartz, Z., Wieland, M., Rupp, F., Geis-Gerstorfer, J., Cochran, D.L. and Boyan, B.D. (2005) High Surface Energy Enhances Cell Response to Titanium Substrate Microstructure. Journal of Biomedical Materials Research A, 74, 49-58. http://dx.doi.org/10.1002/jbm.a.30320

[5] Deligianni, D.D., Katsala, N., Ladas, S., Sotiropoulou, D., Amedee, J. and Missirlis, Y.F. (2001) Effect of Surface Roughness of the Titanium Alloy Ti-6Al-4V on Human Bone Marrow Cell Response and on Protein Adsorption. Bio- 
materials, 22, 1241-1251. http://dx.doi.org/10.1016/s0142-9612(00)00274-X

[6] Ellingsen, J.E. (1998) Surface Configurations of Dental Implants. Periodontology 2000, 17, 36-46. http://dx.doi.org/10.1111/j.1600-0757.1998.tb00121.x

[7] Ramires, P.A., Romito, A., Cosentino, F. and Milella, E. (2001) The Influence of Titanium/Hydroxyapatite Composite Coatings on in Vitro Osteoblasts Behaviour. Biomaterials, 22, 1467-1474. http://dx.doi.org/10.1016/S0142-9612(00)00269-6

[8] Kilpadi, D. and Lemons, J. (1994) Surface Energy Characterization of Unalloyed Titanium Implants. Journal of Biomedical Materials Research, 28, 1419-1425. http://dx.doi.org/10.1002/jbm.820281206

[9] Doundoulakis, J.H. (1987) Surface Analysis of Titanium after Sterilization: Role in Implant-Tissue Interface and Bioadhesion. The Journal of Prosthetic Dentistry, 58, 471-478. http://dx.doi.org/10.1016/0022-3913(87)90279-4

[10] Baier, R.E., Meyer, A.E., Natiella, J.R., Natiella, R.R. and Carter, J.M. (1984) Surface Properties Determine Bioadhesive Outcomes: Methods and Results. Journal of Biomedical Materials Research, 18, 327-355. http://dx.doi.org/10.1002/jbm.820180404

[11] Nanci, A., Wuest, J.D., Peru, L., Brunet, P., Sharma, V., Zalzal, S. and McKee, M.D. (1998) Chemical Modification of Titanium Surfaces for Covalent Attachment of Biological Molecules. Journal of Biomedical Materials Research, 40, 324-335. http://dx.doi.org/10.1002/(SICI)1097-4636(199805)40:2<324::AID-JBM18>3.0.CO;2-L

[12] Buser, D., Broggini, N., Wieland, M., Schenk, R.K., Denzer, A.J., Cochran, D.L., Hoffmann, B., Lussi, A. and Steinemann, S.G. (2004) Enhanced Bone Apposition to a Chemically Modified SLA Titanium Surface. Journal of Dental Research, 83, 529-533. http://dx.doi.org/10.1177/154405910408300704

[13] Wennerberg, A., Albrektsson, T. and Andersson, B. (1996) Bone Tissue Response to Commercially Pure Titanium Implants Blasted with Fine and Coarse Particles of Aluminum Oxide. International Journal of Oral Maxillofacial Implants, 11, 38-45.

[14] Rosa, A.L. and Beloti, M.M. (2003) Effect of cpTi Surface Roughness on Human Bone Marrow Cell Attachment, Proliferation, and Differentiation. Brazilian Dental Journal, 14, 16-21.

[15] Rosa, A.L. and Beloti, M.M. (2003) Rat Bone Marrow Cell Response to Titanium and Titanium Alloy with Different Surface Roughness. Clinical Oral Implants Research, 14, 43-48. http://dx.doi.org/10.1034/j.1600-0501.2003.140106.x

[16] Xavier, S.P., Carvalho, P.S., Beloti, M.M. and Rosa, A.L. (2003) Response of Rat Bone Marrow Cells to Commercially Pure Titanium Submitted to Different Surface Treatments. Journal of Dentistry, 31, 173-180. http://dx.doi.org/10.1016/s0300-5712(03)00027-7

[17] Boyan, B.D., Bonewald, L.F., Paschalis, E.P., Lohmann, C.H., Rosser, J., Cochran, D.L., Dean, D.D., Shwartz, Z. and Boskey, A.L. (2002) Osteoblast-Mediated Mineral Deposition in Culture Is Dependent on Surface Microtopography. Calcified Tissue International, 71, 519-529. http://dx.doi.org/10.1007/s00223-001-1114-y

[18] Zhao, G., Raines, A.L., Wieland, M., Schwartz, Z. and Boyan, B.D. (2007) Requirement for Both Micron- and Submicron Scale Structure for Synergistic Responses of Osteoblasts to Substrate Surface Energy and Topography. Biomaterials, 28, 2821-2829. http://dx.doi.org/10.1016/j.biomaterials.2007.02.024

[19] Lohmann, C.H., Sagun Jr., R., Sylvia, V.L., Cochran, D.L., Dean, D.D., Boyan, B.D. and Schwartz, Z. (1999) Surface Roughness Modulates the Response of MG63 Osteoblast-Like Cells to 1,25- $(\mathrm{OH})_{2} \mathrm{D}_{3}$ through Regulation of Phospholipase $\mathrm{A}_{2}$ Activity and Activation of Protein Kinase A. Journal of Biomedical Materials Research, 47, 139-151. http://dx.doi.org/10.1002/(SICI)1097-4636(199911)47:2<139::AID-JBM4>3.0.CO;2-2

[20] Deboni, M.C.Z., Jaeger, M.M.M. and Araujo, N.S. (1996) Development and Characterization of Osteoblast-Like Cells Line. Revista da Faculdade de Odontologia da Universidade de São Paulo, 3, 220-229.

[21] De Lavos-Valareto, I.C., Deboni, M.C.Z., Azambuja Jr., N. and Marques, M.M. (2002) Evaluation of the Titanium Ti-6Al-7Nb Alloy with and without Plasma-Sprayed Hydroxyapatite Coating on Growth and Viability of Cultured Osteoblast-Like Cells. Journal of Periodontology, 73, 900-905. http://dx.doi.org/10.1902/jop.2002.73.8.900

[22] Togashi, A.Y., Cirano, F.R., Marques, M.M., Pustglioni, F.E. and Lima, L.A. (2007) Characterization of Bone Cells Obtained from Calvaria of Neonatal Rats (Osteo-1) after Serial Subculture. Journal of Applied Oral Science, 15, $442-$ 447. http://dx.doi.org/10.1590/S1678-77572007000500013

[23] Lai, H.C., Zhuang, L.F., Liu, X., Wieland, M., Zhang, Z.Y. and Zhang, Z.Y. (2010) The Influence of Surface Energy on Early Adherent Events of Osteoblast on Titanium Substrates. Journal of Biomedical Materials Research A, 93, 289296.

[24] Lowry, O.H., Rosebrough, N.J., Farr, A.L. and Randall, R.J. (1951) Protein Measurement with the Folin Phenol Reagent. Journal of Biological Chemistry, 193, 265-275.

[25] Reddy, G.K. and Enwemeka, C.S. (1996) A Simplified Method for the Analysis of Hydroxyproline in Biological Tissues. Clinical Biochemistry, 29, 225-229. http://dx.doi.org/10.1016/0009-9120(96)00003-6 
[26] Anselme, K. and Bigerelle, M. (2006) Statistical Demonstration of the Relative Effect of Surface Chemistry and Roughness on Human Osteoblast Short-Term Adhesion. Journal of Materials Science: Materials in Medicine, 17, 471479. http://dx.doi.org/10.1007/s10856-006-8475-8

[27] An, N., Rausch-fan, X., Wieland, M., Matejka, M., Andrukhov, O. and Schedle, A. (2012) Initial Attachment, Subsequent Cell Proliferation/Viability and Gene Expression of Epithelial Cells Related to Attachment and Wound Healing in Response to Different Titanium Surfaces. Dental Materials, 28, 1207-1214. http://dx.doi.org/10.1016/j.dental.2012.08.007

[28] Groessner-Schreiber, B. and Tuan, R.S. (1992) Enhanced Extracellular Matrix Production and Mineralization by Osteoblasts Cultured on Titanium Surfaces in Vitro. Journal Cell Science, 101, 209-217.

[29] Wall, I., Donos, N., Carlqvist, K., Jones, F. and Brett, P. (2009) Modified Titanium Surfaces Promote Accelerated Osteogenic Differentiation of Mesenchymal Stromal Cells in Vitro. Bone, 45, 17-26. http://dx.doi.org/10.1016/j.bone.2009.03.662

[30] Vlacic-Zischke, J., Hamlet, S.M., Friis, T., Tonetti, M.S. and Ivanovski, S. (2011) The Influence of Surface Microroughness and Hydrophilicity of Titanium on the Up-Regulation of TGF-Beta/BMP Signalling in Osteoblasts. Biomaterials, 32, 665-671. http://dx.doi.org/10.1016/j.biomaterials.2010.09.025

[31] Olivares-Navarrete, R., Hyzy, S.L., Hutton, D.L., Dunn, G.R., Appert, C., Boyan, B.D. and Schwartz, Z. (2011) Role of Non-Canonical Wnt Signaling in Osteoblast Maturation on Microstructured Titanium Surfaces. Acta Biomaterialia, 7, 2740-2750. http://dx.doi.org/10.1016/j.actbio.2011.02.030

[32] Chakravorty, N., Ivanovski, S., Prasadam, I., Ross, C.R., Oloyede, A. and Xiao, Y. (2012) The microRNA Expression Signature on Modified Titanium Implant Surfaces Influences Genetic Mechanisms Leading to Osteogenic Differentiation. Acta Biomaterialia, 8, 3516-3523. http://dx.doi.org/10.1016/j.actbio.2012.05.008

[33] Boyan, B.D., Lohmann, C.H., Sisk, M., Liu, Y., Sylvia, V.L., Cochran, D.L., Dean, D.D. and Schwartz, Z. (2001) Both Cyclooxygenase-1 and Cyclooxygenase-2 Mediate Osteoblast Response to Titanium Surface Roughness. Journal of Biomedical Material Research, 55, 350-359. http://dx.doi.org/10.1002/1097-4636(20010605)55:3<350::AID-JBM1023>3.0.CO;2-M

[34] Schwartz, Z., Lohmann, C.H., Sisk, M., Cochran, D.L., Sylvia, V.L., Simpsom, J., Dean, D.D. and Boyan, B.D. (2001) Local Factor Production by MG63 Osteoblast-Like Cells in Response to Surface Roughness and 1,25-(OH) ${ }_{2} \mathrm{D}_{3}$ Is Mediated via Protein Kinase C- and Protein Kinase A-Dependent Pathways. Biomaterials, 22, 731-741. http://dx.doi.org/10.1016/s0142-9612(00)00241-6

[35] Ong, J.L., Carnes, D.L., Cardenas, H.L. and Cavin, R. (1997) Surface Roughness of Titanium on Bone Morphogenetic Protein-2 Treated Osteoblast Cells in Vitro. Implant Dentistry, 6, 19-24. http://dx.doi.org/10.1097/00008505-199700610-00004

[36] Ku, C.H., Pioletti, D.P., Browne, M. and Gregson, P.J. (2002) Effect of Different Ti-6Al-4V Surface Treatments on Osteoblasts Behaviour. Biomaterials, 23, 1447-1454. 